\title{
O reparo "ético" da parede abdominal
}

\section{The "ethical" repair of the abdominal wall}

\author{
tCBC-go Renato Miranda de Melo
}

\begin{abstract}
A expressão pode até ser nova, mas o conceito é antigo, bem antigo.
\end{abstract}

Gradativamente, vimos assistindo a uma verdadeira inversão de valores, dentro e fora da Medicina, em que produtos valem mais do que serviços, um pedaço de plástico custa mais do que o trabalho para implantá-lo. O que induz à cura não é mais o cuidado médico, mas qualquer coisa que se aponha ao corpo, pois os fenômenos reparatórios decretaram falência, por não conseguirem mais responder à demanda biológica, na velocidade em que os tempos modernos estão a exigir. Uma nova onda de interferência máxima foi deflagrada em nossa mais que milenar arte cirúrgica, abrindo espaço, agora, para os tratamentos por substituição de componentes: mulher jovem, nuligesta, com mamas grandes (?), faz mastectomia redutora; engravida, engorda e não emagrece mais; faz cirurgia bariátrica, aí emagrece demais, as mamas caem, põe silicone. E por aí vai... Para piorar, vivemos o famigerado imediatismo, alimentado pela noção equivocada de globalização, que apenas induz à acumulação pura, desmesurada e estéril.

Mas qual é o impacto que a "medicina dos plásticos" está trazendo ao nosso paciente? Essa é mais uma onda em Medicina, ou é uma tendência mundial e inexorável? Os resultados são efetivamente melhores e mais duradouros? Os custos são menores, já que é tudo de plástico e feito por máquinas? Sendo assim, maior número de pessoas é beneficiado? Em que medida ela pode e deve ser negociada? E quem deve entrar na roda de negociações: o paciente, o médico, o diretor técnico do hospital, o plano de saúde, o distribuidor, o fabricante, o secretário de saúde ou o ministro novamente? O paciente está mais satisfeito? Ele aceita de bom grado a possibilidade real de reintervenções, que possam advir de complicações ou de efeitos colaterais ao material implantado? O cirurgião tem menos trabalho ao tratar assim? As respostas a essas e outras indagações certamente são sim e não, a depender da maneira como esses dispositivos forem implantados. Eis a questão!

Já aprendemos que toda cautela é pouca ante o ato médico, cuja natureza e possíveis consequências obrigam-nos a trabalhar com variáveis pouco controláveis e margem de erro bastante estreita. É compreensível, portanto, a "corrida" dos novos médicos para especialidades atreladas à alta tecnologia, que oferecem resultados objetivamente quantificáveis ou mensuráveis e que guardam uma "distância segura" do paciente, examinado a partir de antecâmaras ou por fragmentos dele extraídos. E é exatamente isso o que espanta: o médico alijar-se, deliberadamente, do encadeamento das decisões, do processo, do compromisso, ao mesmo tempo penoso e gratificante, de acompanhar o paciente desde a entrevista inicial até a convalescença. O cirurgião tem esse privilégio.

Havia um tempo, não tão remoto assim, que para tratar, o cirurgião dispunha apenas dos seus conhecimentos de anatomia, de fisiologia, de anatomia patológica, de tática e de técnica operatórias, além de alguns fios de sutura, como o categute, o algodão e a seda. De sua equipe, faziam parte os auxiliares (escolhidos a dedo), o anestesista (também) e a equipe de enfermeiras, em geral mais rigorosas do que o próprio cirurgião. Havia também a figura do clínico, que fazia a triagem e o encaminhamento daqueles que não respondiam ao tratamento medicamentoso, ou cuja doença já havia avançado o suficiente, exigindo medidas menos conservadoras. Mas ele também ajudava a preparar o enfermo e o acompanhava no pré, no per e no pós-operatório. O paciente era acolhido e cuidado, muito bem cuidado. Tudo o que o cirurgião tinha a fazer - não que fosse pouco - era restaurar, recompor ou remontar, na medida do possível, a anatomia perdida, após corrigir os componentes da doença. Com isso, oferecia ao órgão lesado a possibilidade, maior ou menor, de resgatar a sua fisiologia; e, ao paciente, a chance de restabelecer a sua saúde. Tratava o todo, pela parte; e a parte, pelo todo. O talento, a vocação, o perfil, o apuro do cirurgião (e de sua equipe) eram agentes facilitadores e colocavam-no na trilha da competência e do reconhecimento. A Cirurgia estava a serviço do cirurgião, e este a serviço daquela, e ambos a serviço do paciente. Em uma palavra: ética.

Tempos remotos? Sim. Tempos futuros? Talvez... Tempo presente? Não se sabe. Mas isso é atemporal, depende exclusivamente das escolhas que fazemos e das posturas que assumimos.

E a parede abdominal? A parede abdominal está intimamente relacionada com outros sistemas corporais, por exemplo, o digestivo, o circulatório, o respiratório e o gênito-urinário. Sem ela, ficaria bastante difícil vomitar, evacuar, tossir, espirrar, inspirar e expirar profundamente, favorecer o retorno venoso e linfático, perfundir os rins e o fígado, ejacular ou expulsar o feto, para citar algumas de suas ações coadjuvantes. Portanto, a parede abdominal é, ou sempre foi, verdadeiro órgão multissistêmico. E como tal deveria ser abordada e tratada, ou seja, procurando 
sempre restituir a sua função, a partir do reparo da sua estrutura (anatomia).

Diante de um grande defeito parietal - seja aquele provocado por uma ressecção em bloco ou por uma hérnia incisional complexa - há que se observar alguns princípios, independente da maneira como o cirurgião sinta-se apto a fazê-lo, seja por via convencional, laparoscópica, ou uma combinação das duas. São eles: avaliar, compensar e preparar o paciente, sobretudo do ponto de vista ventilatório; reduzir o conteúdo herniado e cerrar o defeito; não provocar hipertensão na cavidade abdominal nem nas linhas de sutura; refazer a linha alba, sempre que possível, para devolver à parede a capacidade distensiva e de contração harmônica (suporte muscular dinâmico); prevenir as aderências, não apenas para se prevenirem os quadros obstrutivos, mas para facilitar ou até viabilizar as reoperações abdominais, em uma população permanentemente exposta a traumatismos e cada vez mais longeva, candidata por isso aos tratamentos oncológicos. E há outro grande desafio: o de tratar a pele desses pacientes. É muitíssimo frequente, que eles apresentem cicatrizes hipertróficas, retráteis, que formam recessos e deformidades, quando não ulceram e se infectam, podendo chegar mesmo à ruptura espontânea e à evisceração. Além disso, o abdome em avental, quando presente, macera a pele nas virilhas, permitindo o crescimento de bactérias e de fungos, cujo controle definitivo só é possível com a ressecção da pele e da gordura redundantes. Por fim, devemos oferecer um resultado cosmeticamente aceitável, porque isso eleva a auto-estima e a percepção que ambos - pacientes e médicos - temos de tratamento completo ou global nesses casos. Em uma palavra: ética.

Se conseguirmos conduzir a nossa prática, frente aos desafios impostos pela parede abdominal doente, trabalharemos, acima de tudo, com o foco nas necessidades do paciente. Isso poderá exigir toneladas de plástico, não importa. O que realmente importa é saber que nós, médicos, não estaremos colocando pedaços de plástico em seres de plástico... 